NBER WORKING PAPER SERIES

\title{
MACROECONOMIC FACTORS AND ANTIDUMPING FILINGS: EVIDENCE FROM FOUR COUNTRIES
}

\author{
Michael M. Knetter \\ Thomas J. Prusa \\ Working Paper 8010 \\ http://www.nber.org/papers/w8010 \\ NATIONAL BUREAU OF ECONOMIC RESEARCH \\ 1050 Massachusetts Avenue \\ Cambridge, MA 02138 \\ November 2000
}

We would like to thank Andy Bernard, Bruce Blonigen, Mendy Rudolph, and seminar participants at the NBER ITI Summer Institute, Tokyo University, and Penn State University for useful comments and discussion. We are especially appreciative of the assistance of Jorge Miranda in compiling the AD filing database. Finally, we thank Tara Nells for her excellent research assistance. The views expressed in this paper are those of the authors and not necessarily those of the National Bureau of Economic Research.

(C) 2000 by Michael M. Knetter and Thomas J. Prusa. All rights reserved. Short sections of text, not to exceed two paragraphs, may be quoted without explicit permission provided that full credit, including (C) notice, is given to the source. 
Macroeconomic Factors and Antidumping Filings:

Evidence from Four Countries

Michael M. Knetter and Thomas J. Prusa

NBER Working Paper No. 8010

November 2000

JEL No. F13

\begin{abstract}
This paper examines the relationship between antidumping filings and macroeconomic factors. We show that real exchange rate fluctuations affect the two criteria for dumping in opposite ways, making the overall effect on filings ambiguous in theory. Interestingly, no such ambiguity is evidenced in the data. Examining the filing patterns of the four major users of AD law during the 1980--98 period we find that real exchange rates and domestic real GDP growth both have statistically significant impacts on filings. Bilateral filing data indicate that a one-standard deviation real appreciation of the domestic currency increases filings by $33 \%$ while a one-standard deviation fall in domestic real GDP increases filings by $23 \%$.
\end{abstract}

Michael M. Knetter

Tuck School of Business

Dartmouth College

Hanover, NH 03755

and NBER

knetter@dartmouth.edu
Thomas J. Prusa

Department of Economics

Rutgers University

New Brunswick, NJ 08901

and NBER

prusa@econ.rutgers.edu 


\section{Introduction}

The GATT/WTO antidumping (AD) statute requires two criteria to be met in order to impose duties on foreign suppliers named in antidumping suits. First, there must be evidence that the domestic industry has suffered "material injury" (e.g., a decline in profitability) as a result of foreign imports. Second, the foreign suppliers must be found to be pricing at "less than fair value" (LTFV). This latter criterion can be determined in either of two ways: (1) by showing that the price charged in the domestic market by the foreign suppliers is below the price charged for the same product in other markets (i.e., the "price-based" method) or (2) by showing that the price charged in the domestic market is below an estimate of cost plus a normal return (i.e., the "constructed-value" method).

The focus of this paper is on how macroeconomic factors in general, and fluctuations in real exchange rates in particular, can affect the determination of each of these criteria. At a theoretical level it is not obvious how real exchange rates will affect filing behavior, given the criteria laid out above. For example, when the domestic currency strengthens, the normal response of foreign firms is to increase the foreign currency price of shipments to the domestic market relative to other destinations, but by less than the appreciation of the domestic currency. ${ }^{1}$ An increase in the price of shipments to the domestic market obviously reduces

\footnotetext{
${ }^{1}$ The relationship between exchange rate fluctuations and destination-specific pricing of exports is known as pricing-to-market behavior. The evidence on pricing-to-market varies by industry (see Goldberg and Knetter (1997)), but the median price response to a real exchange rate change across industries studied in the literature is close to $50 \%$-i.e., half of the movement in the real exchange rate is offset by destination-price adjustment.
} 
the chance that the foreign firm is guilty of LTFV pricing. Thus, a strong (weak) domestic currency makes it less (more) likely that the foreign firm is guilty of LTFV pricing.

However, since the price increase in foreign currency units does not typically offset the full effect of the domestic currency appreciation, the domestic currency price of foreign goods will fall. This would be expected to reduce the profits of domestic producers in the same industry by lowering their margins or market share. $^{2}$ Thus, a strong (weak) domestic currency should increase (decrease) the likelihood of a finding of material injury to the domestic industry.

Empirically which effect is more important is an open question. Within the business community there appears to be a belief that a strong domestic currency precipitates filings. For example, in its March 26, 1999 Economic Analyst publication, Goldman Sachs documents a rise in AD cases associated with an increase in the value of the trade-weighted U.S. dollar. Interestingly, the existing empirical literature reaches the opposite conclusion. In particular, using a dataset based on U.S. AD filings from 1982-87 Feinberg (1989) finds that filings increase with a weaker dollar.

Fluctuations in economic activity, both in the importing country and the exporting country, might also affect filing decisions. Clearly, a slump in economic

\footnotetext{
${ }^{2}$ Note that the dollar price of imported goods will fall relative to domestic goods with a real appreciation of the dollar provided the foreign firm does not completely offset the relative cost change with a markup change. The special case in which markups are adjusted to fully offset the effects of currency movements is known as "complete pricing-to-market" in the literature. The opposite case, in which exchange rate changes are fully passed-through to foreign buyers is known as "full pass-through."
} 
activity in the importing country makes it more likely domestic firms perform poorly which may facilitate a finding of material injury. Also, a weak economy in the importing country might naturally lead foreign firms to reduce prices on shipments to the importing country. This could increase the likelihood of pricing below fair value. Thus we would expect that import country GDP will be negatively related to filings. It is less clear how export country GDP is related to filings. One possibility is that a weak foreign economy increases the likelihood that foreign firms will cut prices to maintain overall levels of output. While such behavior might cause injury to domestic firms, it is not clear that it would trigger pricing below "fair value" in the price-based sense, since foreign firms would presumably be lowering prices to all markets (especially their own home market). It is possible, however, that generally low prices would increase the chance of LTFV using the "constructed-value" method.

The conventional wisdom on these issues seems to be that the more difficult test to pass for a successful antidumping filing (i.e., one that leads to duties being imposed on the foreign firm) is the material injury criterion. For instance, over the past 20 years only 28 of 800 U.S. cases received negative LTFV determinations; by contrast, there have been over 300 negative injury determinations. This fact might suggest that more antidumping cases would be filed when exchange rates or output fluctuations improve the odds of an affirmative material injury decision-i.e., when the domestic currency is strong in real terms or when the domestic country is in recession. However, the exact relationship will depend on the sensitivity of prices and profits to exchange rates changes and the correlation between exchange rates 
and other macroeconomic variables. Furthermore, the criteria for imposition of duties may be implemented somewhat differently across other countries. It is therefore an empirical issue.

Our goal in this paper is to determine the relationship between filings, real exchange rates, and economic activity. First, we develop a model that links currency fluctuations to the criteria for dumping. We presume that the incentive to file an $\mathrm{AD}$ case is positively related to the likelihood of affirmative decisions on the injury and LTFV criteria. Then, we investigate the empirical relationship between filings and macro factors since 1980 for four of the primary AD users (Australia, Canada, the European Union, and the U.S.). ${ }^{3}$ We believe systematic evidence that macro factors are related to filings would be further ammunition for the view that antidumping law is a tool of protectionism that is frequently abused. While fluctuations in real GDP and real exchange rates are certain to affect industry equilibria, they are unlikely to be systematically associated with malevolent behavior by foreign firms. A finding that dumping allegations are related to macro factors would seem to suggest that foreign firms are potentially being held responsible for the impact of factors beyond their control. ${ }^{4}$

\footnotetext{
${ }^{3}$ Several recent papers study issues related to those examined in this paper. Hens, et. al. (1999) study pricing-to-market in a reciprocal duopoly model. However, they do not address the issue of how pricing-to-market is affected by AD law. Blonigen and Haynes (1999) study the pricing behavior of firms following the imposition of $\mathrm{AD}$ duties. We are interested in the pricing behavior prior to an AD investigation. Finally, a number of papers including Baldwin and Steagall (1994) and Krupp (1994) examine how various factors influence the ITC injury decision. We focus not on the injury determination but on the number of filings in this work.

${ }^{4}$ This view is echoed in the Goldman Sachs Economic Analyst which claims that "the correlation between the number of AD cases initiated and the change in the G7 trade-weighted dollar index suggests that domestic producers have been seeking protection against adverse market conditions, not against anti-competitive dumping."
} 


\section{The Model}

This section will setup a two-period duopoly model that identifies how AD law complicates the foreign firm's pricing decision. We begin by assuming that there are two firms, one domestic and one foreign. In each period, the firms produce differentiated products that are close, but not perfect, substitutes for one another. The domestic firm services the domestic market with local production while the foreign firm exports to the domestic market.

For simplicity we will ignore the foreign firm's behavior in its own home market. This assumption can be justified on two grounds. First, it avoids needless complication without much cost. Second, in the majority of AD investigations the foreign firm's home market pricing is not directly relevant to the investigation. This is the case, for instance, when a constructed-value approach is used to calculate the LTFV margin. ${ }^{5}$ Also, when home market sales are too small (or do not exist), or when the exporter operates in a centrally planned economy, the dumping calculation will be based on sales of a comparable product sold by a third party in another market. In all these circumstances the home market price used in the AD investigation is largely outside the control of the foreign firm.

As discussed by McKinnon (1979) and Giovannini (1988) the foreign firm faces a decision as to which currency to use when announcing its price. We will not analyze that problem here, but rather follow Feenstra (1989) and assume that the

\footnotetext{
${ }^{5}$ Clarida (1992) reports that about two-thirds of US AD cases use the constructed value method. Messerlin (1989) reports an even higher percentage of EU cases use the constructed value method.
} 
foreign firm sets its price in the domestic currency and then uses the exchange rate to convert into foreign currency units. Let $e_{t}$ denote the bilateral exchange rate at time $t$, expressed as foreign currency per unit of domestic currency. Let $q_{t}\left(p_{t}\right)$ denote the foreign (domestic) firm's price and $y_{t}=y\left(q_{t}, p_{t}\right)\left(x_{t}=x\left(q_{t}, p_{t}\right)\right)$ denote the foreign (domestic) firm's quantity in period $t, t=1,2$. Let $\varphi\left(y_{t}\right)$ and $\phi\left(x_{t}\right)$ denote the foreign and domestic firms' costs of production.

If $\mathrm{AD}$ duties are not present, the domestic firm will earn profit $\pi_{t}\left(q_{t}, p_{t}\right)$, and the foreign firm will earn $\Pi_{t}\left(q_{t}, p_{t}, e_{t}\right)$,

$$
\begin{aligned}
\pi_{t}\left(q_{t}, p_{t}\right) & =p_{t} x\left(q_{t}, p_{t}\right)-\phi\left(x\left(q_{t}, p_{t}\right)\right) \\
\Pi_{t}\left(q_{t}, p_{t}, e_{t}\right) & =e_{t} q_{t} y\left(q_{t}, p_{t}\right)-\varphi\left(y\left(q_{t}, p_{t}\right)\right)
\end{aligned}
$$

It is important to realize that $\pi$ is denominated in the domestic currency while $\Pi$ is denominated in the foreign currency.

When firms compete under the specter of AD law, the foreign firm's pricing decision is complicated by the LTFV and injury determinations. We will say that the foreign firm has sold at LTFV if its price in the domestic market during the first period is less than some benchmark price (denominated in the foreign currency). In other words, LTFV sales are said to occur if $e_{1} q_{1}<q_{H}$, where we are implicitly assuming that the benchmark price is calculated using the constructed value method. ${ }^{6}$

\footnotetext{
${ }^{6}$ The model is equally relevant for a price-based case in which the comparison price is independent of $e$. For example, $q_{H}$ could be the price in the home market if there are constant marginal costs and no imported inputs.
} 
At this point we will assume that both the domestic and foreign firms only know the general rules by which $q_{H}$ is constructed. In other words, the distribution governing $q_{H}, F(\cdot)$, is common knowledge. We also assume that $F(\cdot)$ is twice-continuously differentiable on support $[0, \bar{q}]$. The probability of a LTFV determination can be written as

$$
\rho^{L}\left(q_{1}, e_{1}\right)=\operatorname{Prob}\left(e_{1} q_{1}<q_{H}\right)=\int_{e_{1} q_{1}}^{\bar{q}} F^{\prime}(x) d x
$$

An injury determination must also be made before duties can be levied. For simplicity, we will say that the domestic firm has been injured if $\pi_{1}\left(q_{1}, p_{1}\right) \leq \pi^{I}+\mu$. In other words, we interpret the injury criterion as establishing a minimum profit level, $\pi^{I}$. However, factors beyond the firms' control - the political environment, the general state of the economy, etc. - create a random component to the injury decision, $\mu$, which we assume is drawn from a twice-continuously differentiable distribution $G(\cdot)$. We assume that $G(\cdot)$ is common knowledge and has zero mean. Thus, the probability that injury occurs is

$$
\rho^{I}\left(q_{1}, p_{1}\right)=\operatorname{Prob}\left(\pi_{1}\left(q_{1}, p_{1}\right)-\pi^{I} \leq \mu\right)=\int_{\pi_{1}\left(q_{1}, p_{1}\right)-\pi^{I}}^{\infty} G^{\prime}(x) d x .
$$

The timing of play is as follows: (1) The exchange rate, $e_{1}$ is realized. (2) Firms announce their first period prices; first period sales and profits are realized. (3) If it desires, the domestic firm can initiate an $\mathrm{AD}$ investigation at a cost of $C$. (4) If a petition is initiated, the government determines whether or not both criteria 
are satisfied and announces its decision. (5) The exchange rate, $e_{2}$ is realized. (6) If dumping is found, a dumping duty is charged; in a manner consistent with current WTO rules, we will model the dumping order as establishing a minimum price, below which the foreign firm cannot sell in the domestic market. We will denote this price as $q_{D}$; the foreign firm collects only $q_{1}$. If dumping is not found, the firms simply announce their second period prices. (7) Second period sales and profits are realized.

\section{Equilibrium Pricing and Pricing-to-Market without Antidumping Law}

Without the threat of AD the firms simply maximize their profit in each period. Letting $\delta$ denote the common discount factor we can write the firms' objectives as

$$
\begin{aligned}
& \max _{\left\{p_{1}, p_{2}\right\}} \pi=\pi_{1}\left(q_{1}, p_{1}\right)+\delta \pi_{2}\left(q_{2}, p_{2}\right), \\
& \max _{\left\{q_{1}, q_{2}\right\}} \Pi=\Pi_{1}\left(q_{1}, p_{1}, e_{1}\right)+\delta \Pi_{2}\left(q_{2}, p_{2}, e_{2}\right) .
\end{aligned}
$$

The first order conditions can be written as

$$
\begin{aligned}
& \frac{\partial \pi_{t}}{\partial p_{t}}=x_{t}+p_{t} \frac{\partial x_{t}}{\partial p_{t}}-\phi^{\prime}\left(x_{t}\right) \frac{\partial x_{t}}{\partial p_{t}}=0 \\
& \frac{\partial \Pi_{t}}{\partial q_{t}}=e_{t} y_{t}+e_{t} q_{t} \frac{\partial y_{t}}{\partial q_{t}}-\varphi^{\prime}\left(y_{t}\right) \frac{\partial y_{t}}{\partial q_{t}}=0
\end{aligned}
$$

We will assume that the second order conditions are satisfied, that the ownprice effects dominate the cross-price effects, that there exists a unique, stable 
Nash equilibrium, and that in equilibrium both firms' prices and output are strictly positive. ${ }^{7}$ Let $\left(q_{t}^{*}\left(e_{t}\right), p_{t}^{*}\left(e_{t}\right)\right)$ denote the Nash equilibrium prices and let the domestic and foreign best response functions be denoted as $\beta\left(q_{t}\right)$ and $\gamma\left(p_{t}, e_{t}\right)$, respectively.

Totally differentiating the first order conditions we can derive the effect of the first period exchange rate on the firms' first period prices:

$$
\left[\begin{array}{c}
\frac{d p_{1}}{d e_{1}} \\
\frac{d q_{1}}{d e_{1}}
\end{array}\right]=\frac{1}{D}\left[\begin{array}{cc}
\frac{-\partial^{2} \Pi_{1}}{\partial q_{1}^{2}} & \frac{\partial^{2} \pi_{1}}{\partial p_{1} \partial q_{1}} \\
\frac{\partial^{2} \Pi_{1}}{\partial q_{1} \partial p_{1}} & \frac{-\partial^{2} \pi_{1}}{\partial p_{1}^{2}}
\end{array}\right]\left[\begin{array}{c}
\frac{\partial^{2} \pi_{1}}{\partial p_{1} \partial e_{1}} \\
\frac{\partial^{2} \Pi_{1}}{\partial q_{1} \partial e_{1}}
\end{array}\right],
$$

where $D$ denotes the determinant of the Jacobian matrix. The assumptions made earlier to guarantee a unique solution also guarantee that $D>0$.

Of most interest is the elasticity of the foreign firm's price with respect to the exchange rate:

$$
\frac{d q_{1}}{d e_{1}} \frac{e_{1}}{q_{1}}=\frac{1}{D}\left[\frac{-\partial^{2} \pi_{1}}{\partial p_{1}^{2}}\right]\left[\frac{y_{1} e_{1}^{2}\left(1+\eta_{1}\right)^{2}}{\varphi^{\prime}\left(y_{1}\right) \eta_{1}}\right]<0
$$

where $\eta_{t}=\left(q_{t} / y_{t}\right) \partial y_{t} / \partial q_{t}$ is the foreign firm's own price elasticity of demand.

The latter is the typical pass-through result found in the literature (Feenstra, 1989; Knetter, 1989) and it implies that when the domestic currency appreciates, the foreign firm lowers its domestic currency price. ${ }^{8}$ Feenstra established con-

\footnotetext{
${ }^{7}$ Friedman (1983) discusses the sufficient conditions for these conditions to hold.

${ }^{8}$ We should point out this result does not depend on which currency the foreign firm uses to set its price. If we suppose instead that the foreign firm sets its price in its home currency, then the above result implies that an appreciation of the domestic currency will raise its foreign currency price.
} 
ditions when pass-through is less than one-for-one, which implies that that the foreign firm's price rises in terms of foreign currency. Empirically, Goldberg and Knetter (1997) find that about half of the movement in the real exchange rate is offset by destination-specific price adjustment.

This result provides the intuition behind the conjecture that exchange rate fluctuations have an ambiguous effect on AD filings. Given the above result, we expect that when the domestic currency appreciates, the foreign firm will lower its domestic currency price by less than the change in the exchange rate. With partial pass-through, this means that an affirmative LTFV determination is less likely (since $e_{1} q_{1}$ increases) and an affirmative injury determination is more likely (since $q_{1}$ falls). We now formally consider how pricing decisions are affected by AD law.

\section{Equilibrium Pricing and Pricing-to-Market with Antidumping Law}

In general, the threat of an $\mathrm{AD}$ action implies that the strategy of simply maximizing profit on a period-by-period basis will not be optimal. Rather, first period pricing decisions influence second period profit.

We therefore need to solve the model recursively. At the beginning of period two, firms know whether duties have been levied. If duties have not been levied, the firms' simply maximize second period profits, just as they did without AD law. Denote this equilibrium as $\left\{q_{2}^{*}, p_{2}^{*}\right\}$. In this case, the firms will earn $\pi_{2}\left(q_{2}^{*}, p_{2}^{*}\right)$ and $\Pi_{2}\left(q_{2}^{*}, p_{2}^{*}, e_{2}\right)$, respectively.

If, on the other hand, dumping has been found, the domestic government 
requires the foreign firm's price equal $q_{D}$. In this case, the domestic firm sets a price $p_{D}=\beta\left(q_{D}\right)$ and will earn profits $\pi_{2}\left(q_{D}, p_{D}\right)$.

The domestic firm's gain when AD duties are imposed can be expressed as

$$
\Delta\left(q_{D}\right) \equiv \pi_{2}\left(q_{D}, p_{D}\right)-\pi_{2}\left(q_{2}^{*}, p_{2}^{*}\right)>0 .
$$

Recall that when dumping duties are levied the foreign firm collects only $q_{1}$ per unit. Thus, the foreign firm's expected loss is

$$
\Gamma\left(q_{D}, e_{2}\right) \equiv \Pi_{2}\left(q_{D}, p_{D}, e_{2}\right)-e_{2}\left(q_{D}-q_{1}\right) y\left(q_{D}, p_{D}\right)-\Pi_{2}\left(q_{2}^{*}, p_{2}^{*}, e_{2}\right)<0 .
$$

For the moment, we will assume that the domestic firm finds it profitable to file an $\mathrm{AD}$ petition. In this case, we can write the $\mathrm{AD}$ law-distorted two-period expected profit functions as

$$
\begin{aligned}
\pi\left(q_{1}, p_{1}\right) & =\pi_{1}\left(q_{1}, p_{1}, e_{1}\right)+\delta\left\{\pi_{2}\left(q_{2}^{*}, p_{2}^{*}\right)+\rho^{I}(\cdot) \rho^{L}(\cdot) \Delta\left(q_{D}\right)-C\right\}, \\
\Pi\left(q_{1}, p_{1}, e_{1}, e_{2}\right) & =\Pi_{1}\left(q_{1}, p_{1}, e_{1}\right)+\delta\left\{\Pi_{2}\left(q_{2}^{*}, p_{2}^{*}, e_{2}\right)+\rho^{I}(\cdot) \rho^{L}(\cdot) \Gamma\left(q_{D}, e_{2}\right)\right\} .
\end{aligned}
$$

The first order conditions are

$$
\begin{gathered}
\frac{\partial \pi(\cdot)}{\partial p_{1}}=\frac{\partial \pi_{1}(\cdot)}{\partial p_{1}}\left[1+\delta \rho_{1}^{I}(\cdot) \rho^{L}(\cdot) \Delta\left(q_{D}\right)\right]=0 \\
\begin{array}{c}
\frac{\partial \Pi(\cdot)}{\partial q_{1}}=\frac{\partial \Pi_{1}(\cdot)}{\partial q_{1}}+\delta \Gamma\left(q_{D}, e_{2}\right)\left[\rho^{L}(\cdot) \frac{\partial \rho^{I}(\cdot)}{\partial \pi_{1}} \frac{\partial \pi_{1}(\cdot)}{\partial q_{1}}+\rho^{I}(\cdot) \frac{\partial \rho^{L}(\cdot)}{\partial q_{1}} e_{1}\right] \\
+\delta \rho^{I}(\cdot) \rho^{L}(\cdot) e_{2} y\left(q_{D}, p_{D}\right)=0
\end{array}
\end{gathered}
$$


The conditions can be interpreted as follows. In both equations the first term is the marginal change to first period profit while the bracketed expression is the net effect of a price change on second period profit. When the firms myopically maximize their first period profits, as they do without AD law, the prices are chosen so that the first term (in each equation) equals zero, as seen in (5)-(6).

For the domestic firm, simply maximizing first period profit (i.e., setting $p_{1}=$ $\left.\beta\left(q_{1}\right)\right)$ is always a solution to (12). Since our focus here is the effect of AD on pass-through behavior, we will assume that this is indeed the unique outcome. ${ }^{9}$

By contrast, simply maximizing first period profits cannot be a solution for the foreign firm. Altering its first period price directly impacts both the LTFV and injury determination. In particular, an increase in the first period price decreases both the probability of injury and LTFV sales. An increase in the first period price also reduces the second period loss if duties are imposed. All three effects lead the foreign firm to announce a higher first period price than it would without AD law. In other words, letting $\gamma_{D}\left(p_{1}, e_{1}\right)$ denote the foreign firm's best response function with $\mathrm{AD}$ law, we know that $\gamma_{D}\left(p_{1}, e_{1}\right) \geq \gamma\left(p_{1}, e_{1}\right)$.

We will once again assume that the second order conditions are satisfied, that there exists a unique, stable Nash equilibrium in this AD-distorted scenario and that in equilibrium both firms' prices and output are strictly positive. Let $\left(q_{1}^{D}\left(e_{1}\right), p_{1}^{D}\left(e_{1}\right)\right)$ denote the Nash equilibrium prices.

Totally differentiating (12) and (13) we can derive the effect of the first period

\footnotetext{
${ }^{9}$ In a related paper, Prusa (1994) establishes conditions when $p_{1}=\beta\left(q_{1}\right)$ is the unique equilibrium response.
} 
exchange rate on pricing:

$$
\left[\begin{array}{c}
\frac{d p_{1}}{d e_{1}} \\
\frac{d q_{1}}{d e_{1}}
\end{array}\right]=\frac{1}{H}\left[\begin{array}{cc}
\frac{-\partial^{2} \Pi}{\partial q_{1}^{2}} & \frac{\partial^{2} \pi}{\partial p_{1} \partial q_{1}} \\
\frac{\partial^{2} \Pi}{\partial q_{1} \partial p_{1}} & \frac{-\partial^{2} \pi}{\partial p_{1}^{2}}
\end{array}\right]\left[\begin{array}{c}
\frac{\partial^{2} \pi}{\partial p_{1} \partial e_{1}} \\
\frac{\partial^{2} \Pi}{\partial q_{1} \partial e_{1}}
\end{array}\right],
$$

where $H$ denotes the determinant of the Jacobian matrix. Given our assumptions that the second order conditions are satisfied and that the own-price effects dominate the cross-price effects, we know that $H>0$.

Now, solving for the effect of the exchange rate on first period pricing:

$$
\begin{aligned}
\frac{d q_{1}}{d e_{1}}= & \frac{1}{H}\left(\frac{-\partial^{2} \pi}{\partial p_{1}^{2}}\right)\left(\frac{\partial^{2} \Pi_{1}}{\partial q_{1} \partial e_{1}}+\delta\left[\rho^{I}(\cdot) \frac{\partial \rho^{L}(\cdot)}{\partial e_{1}} q_{1} e_{2} y\left(q_{D}, p_{D}\right)\right]\right. \\
& \left.+\delta \Gamma(\cdot)\left[\left\{\frac{\partial \rho^{L}(\cdot)}{\partial e_{1}} \frac{\partial \rho^{I}(\cdot)}{\partial \pi_{1}} \frac{\partial \pi_{1}(\cdot)}{\partial q_{1}} q_{1}\right\}+\left\{\rho^{I}(\cdot) e_{1} \frac{\partial^{2} \rho^{L}(\cdot)}{\partial q_{1} \partial e_{1}}+\rho^{I}(\cdot) \frac{\partial \rho^{L}(\cdot)}{\partial q_{1}}\right\}\right]\right)
\end{aligned}
$$

From (7) we know that $\frac{\partial^{2} \Pi_{1}}{\partial q_{1} \partial e_{1}}<0$. The first square bracketed term measures the impact that if duties are levied a higher first period price generates higher second period revenue (because the firm pays lower duties). This term is negative, reflecting that the higher exchange rate lowers the probability of a LTFV determination and thus allows more pass through.

The second square bracketed term is where ambiguity appears. It can be either positive or negative. Recall that $\Gamma(\cdot)<0$ so the second bracketed term is the change in the probability of the foreign firm loss. The first curly bracketed term captures that the foreign firm's incentive to raise its price in order to reduce 
the chance of injury $\left(\frac{\partial \rho^{I}(\cdot)}{\partial \pi_{1}} \frac{\partial \pi_{1}(\cdot)}{\partial q_{1}}<0\right)$ is attenuated by the fact that the exchange rate appreciation reduces the chance of $\operatorname{LTFV}\left(\frac{\partial \rho^{L}(\cdot)}{\partial e_{1}}<0\right)$. In effect, in terms of the LTFV determination the exchange rate appreciation allows the foreign firm to lower its price. The second curly bracketed captures the direct effect of a higher price on the LTFV determination. In general, either effect can dominate. Therefore, we cannot be sure whether AD law will increase or decrease the incentive for incomplete pass-through. If the competing effects roughly offset each other, we would expect incomplete pass-through to be common in the presence of $\mathrm{AD}$ law (as it appears to be in the empirical literature on pass-through and pricing-to-market).

The domestic firm may not, of course, choose to file an AD petition. It will file a petition if

$$
\rho^{I}(\cdot) \rho^{L}(\cdot) \Delta\left(q_{D}\right)-C \geq 0
$$

For some industries the expected payoff from filing will not exceed the costs.

One would expect that filings would be positively related to $\rho^{I}(\cdot), \rho^{L}(\cdot)$, and the expected dumping margin. What we have shown is that exchange rate passthrough creates a trade-off between $\rho^{I}(\cdot)$ and $\rho^{L}(\cdot)$. If the outcome of AD cases tend to hinge on the injury test then we would expect filings to be associated with strong domestic currency. If, on the other hand, the the LTFV test tends to be the crucial determination, then we would expect filings to be associated with weak domestic currency. While our model has taken the dumping duty as exogenous, it is likely that in practice a weak domestic currency increases the dumping margin. 
Therefore, if anything, our model may understate the incentives to file when the domestic currency is weak. This suggests that in our empirical study we must be careful in our interpretation if we find that a weak currency stimulates filings, since this could be due to $\rho^{L}(\cdot)$ or the size of the margin. If, on the other hand, we find that a strong currency stimulates filings then it is clear that the injury determination is the key factor in filings.

\section{Data}

To investigate the relationship between antidumping filings and macroeconomic conditions, we collected data on AD filings by the four largest users: Australia, Canada, the United States, and the European Union. The filing data is available from the GATT/WTO annual reports.

These four users accounted for more than two-thirds of all AD actions filed worldwide since 1980. For each of these four reporting regions (henceforth referred to as "reporting" or "filing" countries), we have aggregate filing data on an annual basis from 1980-98. ${ }^{10}$ For each filing, we know the filing country, the industry, the country named in the filing (i.e., the defendant), and the ultimate determination (injury or no injury). The GATT/WTO reports do not include any information on the dumping margin which precludes us from directly looking at how exchange rate changes affects margins.

Figures 1 displays the number of filings by filing country for our 1980-98

\footnotetext{
${ }^{10}$ Changes in antidumping law in 1979 preclude us from using filing data prior to 1980. Also, due to reporting problems we do not have Australian filings in 1980 and 1981.
} 
sample period. The solid line depicts total filings while the dashed line depicts filings excluding those made by the steel industry, which is generally viewed to be unique in terms of its proclivity to file a large number of cases. ${ }^{11}$ The figures show there is considerable variation in the number of filings from year-to-year. Furthermore, it is clear that filings are related to the business cycle, especially for the United States and Australia. The recessions that began in the early 1980s and early 1990s (the only two in our sample) are associated with large spikes in the number of filings.

The level and variation of filings across filers is also summarized in Table 1. Adjusting for the fact that its filing data is missing for 1980-81, we find that Australia is the heaviest filer of the four regions. This is surprising given that it is the smallest of the four countries by a fairly large margin (e.g., Canada has a population about $50 \%$ greater than Australia, while the U.S. and EU are about 10 times the size of Canada.) Table 2 shows the pattern of bilateral filings across countries. As is readily apparent there is substantial variation in filing across countries. The US and EU have frequently targeted Japanese products while Australia and Canada have both made the US a prime target.

The International Monetary Fund International Financial Statistics CD-ROM provided real GDP data for both the filing countries and the named countries. In our empirical work we perform tests using both aggregate filings and also the number of filings against individual countries. For the aggregate filing behavior, we use the real effective exchange rate index (based on labor costs) for the filing

\footnotetext{
${ }^{11}$ GATT/WTO reports have only identified industry since 1987.
} 
country as reported by the IMF. In our examination of filings against individual foreign countries (i.e., "bilateral filings"), we used bilateral real exchange rates between each of the four filing countries and each country named in at least one antidumping case since 1980. The Economic Research Service of the U.S. Department of Agriculture was a convenient source for bilateral real exchange rates since they report exchange rates in a consistent fashion for virtually all countries in the world. The exchange rate is defined as foreign currency per unit of domestic currency so that an increase in the exchange rate reflects an appreciation of the filing country's currency. Also, we normalize each country's exchange rate by dividing by the sample average.

\section{Empirical Specification and Results}

The theoretical model motivates how filings might be affected by real exchange rates, filing country GDP, and rest of world GDP. The dependent variable in our econometric work will be the number of filings (and for robustness, sometimes number of filings excluding steel - an industry with an unusually large amount of filing activity) occurring in a year.

Since the number of filings is a non-negative count variable, we will estimate the relationship between number of filings and macroeconomic factors using Poisson and Negative Binomial regression as well as OLS, with the belief that the Poisson

or Negative Binomial regression is probably more appropriate given the nature of the data. 
The Poisson regression model assumes that the incidence rate $v$ (the rate per unit time at which happenings occur) is a function of some underlying variables as follows:

$$
v_{j}=e^{\beta_{0}+\beta_{1} x_{1 j}+\beta_{2} x_{2 j}+\cdots+\beta_{k} x_{k j}}
$$

The expected number of occurrences is equal to this incidence rate multiplied by the exposure (the number of units of time over which observations are measured). The exposure is uninteresting in our case since each observation in the data set is the number of AD filings in a one year interval. We believe that the incidence rate is a function of GDP growth in the home and foreign countries, the real exchange rate, and possibly other factors. This Poisson regression is estimated by maximum likelihood.

One feature of the Poisson model that is frequently violated in applications is the equivalence of the expected value and variance of a Poisson random variable. Often, count data exhibit overdispersion with respect to the Poisson model-i.e., the variance of the observed counts exceeds their mean. This is certainly true regarding the data reported in Table 1 . In such cases, an alternative is to assume that the data are generated by a negative binomial random variable, which allows for a variance that is greater than the expected value of the distribution. While we will base most of our conclusions on the negative binomial (NB) regression model, all models yield similar results in terms of the statistical and economic significance of the macroeconomic factors on AD filings.

In addition to method of estimation, another important specification issue is 
the lag structure of the regressors. The legal framework for determining LTFV and material injury offers some guidance here. While not specified under WTO rules, all of the reporting countries generally analyze pricing behavior over the year prior to the filing of the case in order to assess LTFV. By contrast, all of the reporting countries evaluate injury over a longer time horizon. In general, injury is determined over the three years preceding the filing. Given these features of the law, it seems plausible to consider lags from one to three years for our variables. We report results with a one-year lag on the real exchange rate (since we conjecture that exchange rates may be more important for LTFV which is assessed over the one year period) and three year lags on real GDP growth. We have experimented with other lag structures (and contemporaneous values) and are confident that none of our main results is affected by the choice of lag structure.

\section{Annual Data on Aggregate Filings}

Our first set of results is based on the annual number of filings for each of our four reporting units (Australia, Canada, EU, and US). We estimate the number of filings as a function of the real exchange rate, domestic real GDP growth, and rest of world real GDP growth using OLS, Poisson, and NB regression. The real exchange rate variable is normalized by dividing each exchange rate series by its sample mean before taking logs. The real GDP growth variable is the three-year growth rate from $t-3$ to $t$ (i.e., the three years prior to the filing date).

Table 3 reports the results of OLS estimation when the data from all four countries are pooled in a single regression. We experiment in different specifi- 
cations with the set of independent variables and the lag structure used for the real exchange rate and the real GDP variables. In all specifications, the real exchange rate is statistically significant at the $1 \%$ level. The positive sign implies that filings increase as the currency of the filing country strengthens against its trading partners. The range of values of the point estimates for the exchange rate response across these specifications is from 45-55. This implies that a $100 \%$ real appreciation (a unit increase in the log of the real exchange rate) of the filing country's currency would be expected to generate an additional 45-55 AD filings in the following year. Given the linear specification, we can also conclude that a one (two) standard deviation appreciation in the real trade-weighted exchange rate (which is a $12 \%$ (24\%) increase in our exchange rate variable) will tend to be associated with six (12) more AD filings.

Our other macro factors, growth in filing country real GDP and growth in rest of world GDP, have a more ambiguous relationship with AD filings. When filing country real GDP is added to a model with real exchange rates and filing country dummy variables, we find a statistically significant negative relationship, which is what we would expect. For each percentage point decline in real GDP growth between $(t-3)$ and $(t)$, we expect slightly more than three additional filings in year $t$. However, when we add world real GDP growth (defined over the same interval) to this regression, neither GDP variable is statistically significant, although both have a negative sign. Other regressions experiment with changing the window over which the exchange rate variable and GDP variables are defined, but these modifications do not alter the basic finding about the impact of real exchange 
rates. When we use only the most recent year's growth in real GDP, world GDP growth is negative and significant at the $5 \%$ level, suggesting that weak economic conditions outside of the filing country may precipitate more dumping allegations.

As noted earlier, OLS is not the appropriate method for analyzing the count data on AD filings. Table 4 reports the results for the Poisson regression, which uses random effects, rather than fixed effects as were used in the OLS regressions. In these tables, we report "incidence rate ratios" associated with the parameter estimates. The incidence rate ratio (IRR) is the ratio of the counts predicted by the model when the variable of interest is one unit above its mean value and all other variables are at their means to the counts predicted when all variables are at their means. Thus, if the IRR for the real exchange rate is 1.50 , then a one unit increase in the real exchange rate (a 100\% real appreciation given that we use the $\log$ of the real rate) would increase counts by $50 \%$ when all other variables are at their means. The t-statistics are reported for a test of the null hypothesis that the $\operatorname{IRR}=1$, which would imply no relationship between the dependent variable and the regressor.

Our findings regarding the impact of real exchange rates on AD filings are qualitatively the same using the Poisson regression as they were using OLS. In every specification, the real exchange rate is statistically significant at the $1 \%$ level. The range of IRR values associated with the exchange rate coefficients suggest that the count of $\mathrm{AD}$ filings increase anywhere from $240 \%$ to $355 \%$ in response to a $100 \%$ real appreciation of the currency of the filing country. Given a mean number of annual filings around 32, this implies between 77 and 114 additional 
filings due to a $100 \%$ real appreciation. This is a greater quantitative impact than we found using OLS. Because the Poisson model is non-linear, we also calculate the increase in filings for one- and two-standard deviation real appreciations. A one-standard deviation real appreciation is associated with six more filings, while a two-standard deviation real appreciation is associated with 14 filings for the model presented in column (2) of Table 4.

The ambiguity we witnessed regarding the impact of real GDP growth on filings is less apparent in the Poisson model. Filing country real GDP growth over the three-year interval corresponding to the period over which material injury is assessed is negatively and significantly (at the $1 \%$ level) related to filings, whether or not world real GDP growth is included. ${ }^{12}$ A one percentage-point decline in the three-year real GDP growth of the filing country leads to a $5-10 \%$ increase in the number of filings, depending on whether world real GDP is included. A one percentage-point decline in the three-year world real GDP growth leads to a $12 \%$ increase in the number of filings when filing country real GDP growth is included. Both domestic and world GDP growth variables are statistically significant at the $5 \%$ level.

Although the Poisson model seems more intuitively appealing than OLS as a way to analyze the count data on filings, the goodness of fit statistics show that we can reject that the data obey the Poisson distribution at the $1 \%$ level for each model. Usually this is a result of "overdispersion" of the data-i.e.,

\footnotetext{
${ }^{12}$ Note that IRR values less than 1.0 imply a negative relationship between a variable and filing counts.
} 
the variance of the counts exceeds the mean. Based on the means and standard deviations reported in Table 1 this finding is not terribly surprising. Consequently, we consider an alternative count data model, the negative binomial (NB), which is similar to Poisson but does not constrain the relationship between mean and variance.

The results of estimating the NB model on aggregate filings are presented in Table 5. Once again, rather than report the coefficient estimates themselves, we report the IRR associated with each estimate. The first point to note is that the IRR estimates associated with the real exchange rate using the NB model are very similar to those obtained using Poisson. The various models imply that a $100 \%$ real appreciation is associated with an increase in filings of $265 \%$ to $370 \%$. They are all statistically significant at the $1 \%$ level. Clearly, the aggregate filing data suggest that AD filings increase substantially when the filing country currency strengthens in real terms, which contrasts with Feinberg's (1989) result that U.S. filings rise with a weakening currency. ${ }^{13}$

The relationship between real GDP growth and filings in Table 5 is somewhat different from Table 4. Domestic GDP growth is negatively related to filings when it is included alone, but when domestic and world GDP growth are both included, neither variable is statistically significant, although both have the expected neg-

\footnotetext{
${ }^{13}$ Feinberg's analysis differs from ours in two ways. First, he uses quarterly data from 1982-87 for U.S. filings against Korea, Mexico, Brazil, and Japan. Second, he uses a Tobit model with the contemporaneous exchange rate. We have estimated a Tobit model on aggregate filing data with the contemporaneous exchange rate and find that these results are very similar to what is obtained with our specifications reported in Tables 3-5. (Results available upon request.) Thus, it appears that the larger data sample is what leads to the differences in our findings, not the method of estimation or lag structure of the regressions.
} 
ative relationship.

In Table 6 we report results on aggregate filings that include a filing-country specific real exchange rate effect. This allows us only 19 annual observations (17 for Australia) with which to detect a relationship, and more importantly, only a few big swings in the real exchange rate series for each filing country. Here we find that Australia has by far the most pronounced exchange rate effect. The IRR values exceed 50 in some cases and the coefficients are significant at the $1 \%$ level. The U.S. results are "borderline significant" with t-values ranging from 1.6 to 1.8 and IRRs between 2.5 and 2.6. Canada and the EU are never close to being statistically significant and the IRRs tend to be quite small. Part of the problem may be the limited number of observations, which we can rectify by examining filings by "affected country" (i.e., those countries named in a suit as "defendants") for each of our filing countries. These results are discussed below. All of the countries have the expected negative relationship between own GDP growth and filings, but only Canada's is statistically significant.

Since our findings in Tables 3-6 are based on pooling all data on AD filings across our four filing countries, it is of interest to see how these effects hold up for various subsets of the universe of cases. In particular, we are interested in whether our findings hold for filings outside the steel industry (the steel industry files a large fraction of U.S. and Canadian cases). The results are reported in Table 7. When we exclude steel cases from the data, we find that the statistical significance of the real exchange rate effects is similar and the economic significance (given by the magnitude of the IRR in NB regression) is much greater. The real GDP growth 
effects become insignificant (although the point estimates are still negative) when steel cases are excluded from the data. The impact on exchange rates and GDP from excluding steel suggests that AD filings in steel are heavily influenced by the business cycle, but not so much by exchange rates.

\section{Annual Data on Bilateral Filings}

In constructing the database with filings broken down by affected country, we lost a relatively small number of observations due to the inability to construct real exchange rates or real GDP growth over the sample period. Most of the cases involved countries that were part of the former Soviet Union. Once these observations were eliminated, we had a panel dataset with 4 filing countries, 48 affected countries (47 for each filing country), and 19 years (17 for Australia). ${ }^{14}$ We model the number of cases against an affected country by a filing country in each year as a function of the bilateral real exchange rate, filing country real GDP growth, and affected country real GDP growth. The advantage of this dataset, which we believe is substantial, is that the exchange rate and foreign GDP growth variables are more precisely targeted to match the country named in the filings. Following the findings with aggregate filing data, we apply the negative binomial regression model to the data.

The main results are presented in Table 8. These regressions use random effects for each filing-affected country pair. When we estimate a common response to

\footnotetext{
${ }^{14}$ There are still a small number of missing observations for certain affected countries due to missing GDP data.
} 
exchange rates across all filing countries, we find the real exchange rate variable is significant at the $1 \%$ level in all models, with an IRR ranging from 3.28 to 3.37. Although the estimated IRR values are somewhat lower than with aggregate filings, one must keep in mind that the bilateral exchange rate series are much more volatile than the trade-weighted exchange rates used in the aggregate filings (e.g., the standard deviation tends to be about twice as big).

The results when we allow for a filing-country specific response to the real exchange rate with random effects and real GDP growth are reported in column (4). We find that the real exchange rate impact is significant at the $1 \%$ level for Canada (with an IRR of 2.37), the U.S. (IRR equal to 2.09), the EU (IRR equal to 4.23) and Australia (IRR equal to 7.80). The increased detail of the observations has the greatest impact on our results for the EU, which with the aggregate data showed no indication of increased filings when the trade weighted real exchange rate appreciated. In the bilateral data, it is clear that filings rise systematically against countries whose real exchange rates have depreciated against the countries of the EU. The exchange rate impacts are very similar when we allow reporting country-specific real GDP growth effects (column 5). It is worth noting that the country that has filed the most AD cases, Australia, also has the greatest estimated increase in filings in response to a currency appreciation.

In the bilateral filings database, it is also apparent that filing country real GDP growth is negatively and significantly related to the number of filings. In the model with random effects and a common real exchange rate response in column (2), we find that a one percentage-point increase in filing country three- 
year real GDP growth leads to a $3 \%$ decrease in the number of filings (i.e., the IRR is 0.97 ). Adding real GDP growth of the affected countries in column (3) does not affect this estimate. Affected country real GDP growth now appears to be unrelated to the number of filings. The IRR estimates are very close to 1.00 and are never close to being statistically significant. This change in the impact of reporting country and affected country real GDP growth on the number of filings is the main difference from the results obtained with the aggregate filings data. It appears that domestic, but not foreign, recessions systematically provoke more filings.

In terms of the economic significance of the macro factors in the bilateral filings data, we find that for the specifications in columns (1) and (2) of Table 8, a one-standard deviation real appreciation of the domestic currency leads to a $33 \%$ increase in filings, while a two-standard deviation real appreciation results in a $77 \%$ increase. In column (2), the estimated real GDP impact implies that a one standard deviation reduction in real GDP growth leads to a $23 \%$ increase in filings. Based on these estimates, we conclude that both variables are economically significant in explaining the pattern of filings across countries and over time, and that real exchange rates are somewhat more important.

The more robust link between filings and macro factors (especially for filingcountry specific responses to exchange rates) in the bilateral data is no doubt attributable to the increased number of observations and the reduction in noise associated with the real exchange rate. The latter results from the fact that the real exchange rate is matched to a specific affected country, rather than being 
a trade-weighted average rate as it was for the regressions based on aggregate filings. This appears to be a case where aggregation over the affected countries and studying total filings in relation to a trade-weighted exchange rate obscures some interesting information. We place more faith in the bilateral results.

\section{Conclusion}

Antidumping suits have become an increasingly popular form of protection for firms engaged in international markets. This paper has examined how macroeconomic factors in general and the real exchange rate in particular, can influence the probability of affirmative findings for the LTFV and material injury criteria. Using a duopoly model of trade we find that changes in the real exchange rate have offsetting effects on the dumping determinations. A real currency appreciation (depreciation) increases (decreases) the likelihood of injury and decreases (increases) the likelihood of LTFV. Ultimately, which effect is more important in driving AD filings is an empirical matter.

Our empirical work uses data on AD filings from Australia, Canada, the European Union, and the United States. We find that a real appreciation of the filing country's currency will lead to a significant increase in AD filings. This result is at odds with existing research on the subject, but is robust to the method of estimation, to the inclusion of other macroeconomic variables such as real GDP growth, and to the elimination of steel cases in the filing data. The results are strongest when we examine bilateral filings. The economic significance is substantial - a one 
(two) standard deviation real appreciation of the filing country currency leads to a 33\% (77\%) increase in AD filings in our specification that contrains the response to be common across filing countries. We also find that a one standard deviation fall in domestic real GDP growth leads to a $23 \%$ increase in AD filings.

The link between real exchange rates and filings suggests that either foreign firms are being held responsible for factors outside of their control or that foreign firms behave in a "predatory" manner when conditions favor them most. Given the findings of other related literature (Boltuck and Litan, 1991) we are more inclined to believe the former hypothesis, which casts further doubt on the fairness of $\mathrm{AD}$ law.

\section{References}

Baldwin, Robert E., and Jeffrey W. Steagall, "An Analysis of ITC Decisions in Anitdumping, Countervailing Duty, and Safeguard Cases," Weltwirtschaftliches Archiv, 130: (2) 290-308, 1994.

Blonigen, Bruce A. and Stephen E. Haynes, 1999, Antidumping Investigations and the Pass-Through of Exchange Rates and Antidumping Duties, NBER Working Paper No. W7378.

Boltuck, Richard and Robert E. Litan, 1991, Down in the Dumps, (The Brookings Institution: Washington, DC).

Clarida, Richard H., 1993, Entry, dumping, and shakeout, American Economic 
Review, 83, 180-202.

Feenstra, Robert C., "Symmetric Pass-through of tariffs and exchange rates under imperfect competition: An empirical test", Journal of International Economics, 27, 1989, 25-45.

Feinberg, Robert M., "Exchange Rates and Unfair Trade", Review of Economics and Statistics, 1989, pp. 704-07.

Friedman, James, Oligopoly Theory, Cambridge: Cambridge University Press, 1983.

Giovannini, Alberto, "Exchange rates and traded goods prices", Journal of International Economics, 24, 1988, 45-68.

Goldman Sachs, Economic Analyst, March 26, 1999.

Goldberg, Pinelopi and Michael Knetter, "Goods prices and exchange rates: What have we learned?", Journal of Economic Literature, 35, September 1997, 124372 .

Hens, Thorsten, Eckart Jäger, Alan Kirman, and Louis Phlips, 1999, "Exchange Rates and Oligopoly", European Economic Review, 43, 621-48.

Knetter, Michael, "Price discrimination by U.S. and German exporters", American Economic Review, 79, March 1989, 198-210.

Krupp, Cory, "Antidumping Cases in the U.S. Chemical Industry-A Panel Data Approach," Journal of Indusrial Economics, 42:(3) 299-311, September 1994. 
McKinnon, Ronald I., 1979, Money in international exchange (Oxford University Press, New York).

Messerlin, Patrick, 1989, The EC antidumping regulations: A first economic appraisal, 1980-85, Weltwirtschaftliches Archiv, 125, 563-87.

Prusa, Thomas J., "Pricing behavior in the presence of antidumping law", Journal of Economic Integration, 9, 1994, 260-89. 
Table 1. Mean and Standard Deviation of Filings by Source Country, 1980-98

$\begin{array}{lcc} & \text { Avg. Filings Per Year } & \text { Std. Dev. } \\ \text { Australia* } & 41 & 24 \\ \text { Canada } & 23 & 15 \\ \text { EU } & 30 & 9 \\ \text { USA } & 39 & 19 \\ * 1982-98 & & \end{array}$

Page 32 
Table 2: Bilateral Filing Patterns

\begin{tabular}{|c|c|c|c|c|c|}
\hline \multirow[b]{2}{*}{ Affected Country } & \multicolumn{5}{|c|}{ Reporting Country } \\
\hline & Canada & USA & $\begin{array}{c}\text { European } \\
\text { Union }\end{array}$ & Australia & Total \\
\hline Japan & 26 & 88 & 53 & 45 & 212 \\
\hline USA & 83 & 0 & 30 & 63 & 176 \\
\hline South Korea & 25 & 47 & 37 & 47 & 156 \\
\hline PR-China & 14 & 60 & 45 & 37 & 156 \\
\hline Taiwan & 16 & 50 & 11 & 49 & 126 \\
\hline Germany & 31 & 43 & 0 & 47 & 121 \\
\hline Brazil & 15 & 43 & 20 & 23 & 101 \\
\hline Italy & 22 & 35 & 0 & 28 & 85 \\
\hline United Kingdom & 25 & 27 & 0 & 31 & 83 \\
\hline France & 24 & 29 & 0 & 28 & 81 \\
\hline Spain & 18 & 18 & 18 & 9 & 63 \\
\hline Canada & 0 & 41 & 8 & 11 & 60 \\
\hline Thailand & 2 & 10 & 17 & 25 & 54 \\
\hline Czechoslovakia & 8 & 1 & 37 & 7 & 53 \\
\hline Poland & 8 & 8 & 28 & 6 & 50 \\
\hline Belgium-Luxembourg & 11 & 16 & 0 & 22 & 49 \\
\hline India & 5 & 14 & 21 & 7 & 47 \\
\hline Romania & 9 & 9 & 25 & 2 & 45 \\
\hline Mexico & 6 & 21 & 8 & 4 & 39 \\
\hline Singapore & 5 & 5 & 6 & 21 & 37 \\
\hline Sweden & 10 & 8 & 7 & 11 & 36 \\
\hline Hungary & 1 & 5 & 22 & 6 & 34 \\
\hline Netherlands & 5 & 12 & 0 & 16 & 33 \\
\hline Malaysia & 5 & 3 & 11 & 13 & 32 \\
\hline Indonesia & 2 & 3 & 11 & 15 & 31 \\
\hline South Africa & 3 & 6 & 5 & 15 & 29 \\
\hline Hong Kong & 5 & 4 & 10 & 10 & 29 \\
\hline Turkey & 0 & 6 & 14 & 4 & 24 \\
\hline Argentina & 3 & 13 & 1 & 6 & 23 \\
\hline Austria & 3 & 7 & 5 & 8 & 23 \\
\hline New Zealand & 2 & 3 & 0 & 17 & 22 \\
\hline Venezuela & 1 & 17 & 1 & 2 & 21 \\
\hline All Other Countries & 24 & 58 & 58 & 56 & 196 \\
\hline Total & 417 & 710 & 509 & 691 & 2327 \\
\hline
\end{tabular}


Table 3. OLS Estimation of Aggregate Filings

\begin{tabular}{|c|c|c|c|c|c|c|}
\hline Model & (1) & (2) & (3) & (4) & (5) & (6) \\
\hline Constant & $\begin{array}{c}33.10 \\
(16.20)\end{array}$ & $\begin{array}{c}41.00 \\
(10.40)\end{array}$ & $\begin{array}{l}54.70 \\
(9.34)\end{array}$ & $\begin{array}{l}59.30 \\
(8.71)\end{array}$ & $\begin{array}{l}56.90 \\
(7.87)\end{array}$ & $\begin{array}{l}50.60 \\
(8.43)\end{array}$ \\
\hline $\operatorname{rxr}(-1)$ & $\begin{array}{l}52.50 \\
(3.09)\end{array}$ & $\begin{array}{c}54.70 \\
(3.48)\end{array}$ & $\begin{array}{l}45.60 \\
(3.01)\end{array}$ & $\begin{array}{l}47.10 \\
(3.11)\end{array}$ & & $\begin{array}{l}52.70 \\
(3.41)\end{array}$ \\
\hline $\operatorname{rxr}($ avg) & & & & & $\begin{array}{l}46.40 \\
(2.77)\end{array}$ & \\
\hline FGDP (avg) & & & $\begin{array}{c}-3.26 \\
(-3.03)\end{array}$ & $\begin{array}{c}-1.76 \\
(-1.12)\end{array}$ & $\begin{array}{c}-2.63 \\
(-1.68)\end{array}$ & \\
\hline FGDP $(-1)$ & & & & & & $\begin{array}{c}0.48 \\
(0.54)\end{array}$ \\
\hline WGDP (avg) & & & & $\begin{array}{c}-4.05 \\
(-1.31)\end{array}$ & $\begin{array}{c}-2.34 \\
(-0.74)\end{array}$ & \\
\hline WGDP (-1) & & & & & & $\begin{array}{c}-4.24 \\
(-2.11)\end{array}$ \\
\hline Country effects & NO & YES & YES & YES & YES & YES \\
\hline R-squared & 0.11 & 0.24 & 0.32 & 0.32 & 0.28 & 0.27 \\
\hline
\end{tabular}

Notes: rxr is the log of the real exchange rate, FGDP (WGDP) is percentage growth in real GDP of filing country (rest of world) over prior three years (avg) or previous year (-1). $\mathrm{t}$-statistics in parenthesis beneath coefficients. Number of observations $=74$. 
Table 4. Poisson Estimation of Aggregate Filings

$\begin{array}{lcccc}\text { Model } & (1) & (2) & (3) & (4) \\ & & & 3.39 & 3.50 \\ \operatorname{rxr}(-1) & 4.57 & 4.16 & (7.70) & (7.94) \\ \text { FGDP (avg) } & (9.45) & (9.27) & 0.90 & 0.95 \\ & & & (-7.96) & (-2.77) \\ \text { WGDP (avg) } & & & 0.88 \\ & & & (-3.41) \\ \text { Random effects } & \text { NO } & \text { YES } & \text { YES } & \text { YES }\end{array}$

Notes: All variables defined as in Table 2. Estimates are reported as "incidence rate ratios". Number of observations $=74$. $\mathrm{t}$-statistics reported for a test of no effect on filings (which corresponds to an IRR value of 1.0). Poisson goodness of fit test statistic indicates that the data are incompatible with the Poisson model at a marginal significance level of 0.00 . 
Table 5. Negative Binomial Estimation of Aggregate Filings

$\begin{array}{lcccc}\text { Model } & (1) & (2) & (3) & (4) \\ & & & 3.67 & 3.91 \\ \operatorname{rxr}(-1) & 4.18 & 4.69 & (2.80) & (2.96) \\ \text { FGDP (avg) } & (2.75) & (3.40) & 0.93 & 0.97 \\ & & & (-2.05) & (-0.61) \\ \text { WGDP (avg) } & & & 0.89 \\ & & & (-1.21) \\ \text { Random effects } & \text { NO } & \text { YES } & \text { YES } & \text { YES }\end{array}$

Notes: All variables defined as in Table 2. Estimates are reported as "incidence rate ratios". Number of observations $=74$. $\mathrm{t}$-statistics reported for a test of no effect on filings (which corresponds to an IRR value of 1.0). 
Table 6. Negative Binomial Estimation of Aggregate Filings ---

Country Specific Exchange Rate and Domestic GDP Response

\begin{tabular}{|c|c|c|c|c|c|}
\hline Model & (1) & (2) & (3) & (4) & (5) \\
\hline rxr (AUS) & $\begin{array}{c}51.6 \\
(4.46)\end{array}$ & $\begin{array}{c}30.4 \\
(3.58)\end{array}$ & $\begin{array}{c}38.2 \\
(4.09)\end{array}$ & & $\begin{array}{c}36.2 \\
(4.43)\end{array}$ \\
\hline rxr (CAN) & $\begin{array}{c}2.22 \\
(0.55)\end{array}$ & $\begin{array}{c}0.93 \\
(-0.05)\end{array}$ & $\begin{array}{c}1.17 \\
(0.11)\end{array}$ & & $\begin{array}{c}0.11 \\
(-1.33)\end{array}$ \\
\hline rxr (EU) & $\begin{array}{c}2.16 \\
(0.56)\end{array}$ & $\begin{array}{c}2.04 \\
(0.55)\end{array}$ & $\begin{array}{c}1.68 \\
(0.39)\end{array}$ & & $\begin{array}{c}1.98 \\
(0.55)\end{array}$ \\
\hline rxr (US) & $\begin{array}{c}2.51 \\
(1.57)\end{array}$ & $\begin{array}{c}2.62 \\
(1.67)\end{array}$ & $\begin{array}{c}2.60 \\
(1.70)\end{array}$ & & $\begin{array}{c}2.61 \\
(1.79)\end{array}$ \\
\hline FGDP (avg) & & $\begin{array}{c}0.94 \\
(-1.56)\end{array}$ & $\begin{array}{c}1.00 \\
(0.08)\end{array}$ & & \\
\hline WGDP (avg) & & & $\begin{array}{c}0.86 \\
(-1.73)\end{array}$ & & \\
\hline rxr & & & & $\begin{array}{c}3.56 \\
(2.75)\end{array}$ & \\
\hline GDP (AUS) & & & & $\begin{array}{c}.97 \\
(-0.99)\end{array}$ & $\begin{array}{c}.96 \\
(-1.01)\end{array}$ \\
\hline GDP (CAN) & & & & $\begin{array}{c}.82 \\
(-2.99)\end{array}$ & $\begin{array}{c}.79 \\
(-3.50)\end{array}$ \\
\hline GDP (EU) & & & & $\begin{array}{c}.92 \\
(-1.28)\end{array}$ & $\begin{array}{c}90 \\
(-1.67)\end{array}$ \\
\hline GDP (US) & & & & $\begin{array}{c}.97 \\
(-0.63)\end{array}$ & $\begin{array}{c}.95 \\
(-0.90)\end{array}$ \\
\hline
\end{tabular}

Note: All regressions include random effects. All variables defined as in Table 2. Estimates are reported as "incidence rate ratios". Number of observations $=74$. 
Table 7. Negative Binomial Estimation of Aggregate Filings, Excluding Steel

$\begin{array}{lcccc}\text { Model } & (1) & (2) & (3) & (4) \\ & & & \\ \operatorname{rxr}(-1) & 8.64 & 7.95 & 8.74 & \\ & (4.14) & (3.84) & (4.04) & 1.02 \\ \text { FGDP (avg) } & & 0.97 & (-0.49) & (0.36) \\ \text { WGDP (avg) } & (-0.63) & 0.87 & .83 \\ & & (-1.29) & (-1.66) \\ \operatorname{rxr}(\text { AUS) } & & & 56.9 \\ & & & (3.73) \\ \operatorname{rxr}(\mathrm{CAN}) & & & .15 \\ & & & (-1.14) \\ \operatorname{rxr}(\text { EU) } & & & .86 \\ & & & (-0.08) \\ \operatorname{rxr}(\text { US) } & & & 12.0 \\ & & & (4.11)\end{array}$

Note. All specifications include random effects. All variables defined as in Table 2. Estimates are reported as "incidence rate ratios". Number of observations $=74$. 
Table 8. Negative Binomial Estimation of Bilateral Filings

\begin{tabular}{|c|c|c|c|c|c|}
\hline Model & (1) & (2) & (3) & (4) & (5) \\
\hline $\operatorname{rxr}(-1)$ & $\begin{array}{c}3.28 \\
(7.98)\end{array}$ & $\begin{array}{c}3.30 \\
(8.14)\end{array}$ & $\begin{array}{c}3.37 \\
(8.02)\end{array}$ & & \\
\hline $\operatorname{rxr}(\mathrm{AUS})$ & & & & $\begin{array}{c}7.80 \\
(6.29)\end{array}$ & $\begin{array}{c}7.57 \\
(6.14)\end{array}$ \\
\hline $\operatorname{rxr}(\mathrm{CAN})$ & & & & $\begin{array}{c}2.37 \\
(2.54)\end{array}$ & $\begin{array}{c}2.37 \\
(2.55)\end{array}$ \\
\hline $\operatorname{rxr}(\mathrm{EU})$ & & & & $\begin{array}{c}4.23 \\
(4.47)\end{array}$ & $\begin{array}{c}4.22 \\
(4.43)\end{array}$ \\
\hline $\operatorname{rxr}(\mathrm{US})$ & & & & $\begin{array}{c}2.09 \\
(2.93)\end{array}$ & $\begin{array}{c}1.97 \\
(2.66)\end{array}$ \\
\hline FGDP (avg) & & $\begin{array}{c}0.97 \\
(-6.12)\end{array}$ & $\begin{array}{c}0.97 \\
(-5.93)\end{array}$ & $\begin{array}{c}0.97 \\
(-5.36)\end{array}$ & \\
\hline AGDP (avg) & & & $\begin{array}{c}1.00 \\
(-0.43)\end{array}$ & $\begin{array}{c}1.00 \\
(-0.48)\end{array}$ & $\begin{array}{c}1.00 \\
(-0.56)\end{array}$ \\
\hline GDP (AUS) & & & & & $\begin{array}{c}0.96 \\
(-5.01)\end{array}$ \\
\hline GDP (CAN) & & & & & $\begin{array}{c}0.98 \\
(-1.81)\end{array}$ \\
\hline GDP (EU) & & & & & $\begin{array}{c}0.96 \\
(-1.74)\end{array}$ \\
\hline GDP (US) & & & & & $\begin{array}{c}0.98 \\
(-1.71)\end{array}$ \\
\hline No. of Obs. & 3469 & 3469 & 3397 & 3397 & 3397 \\
\hline
\end{tabular}


Total AD Filings

Australia
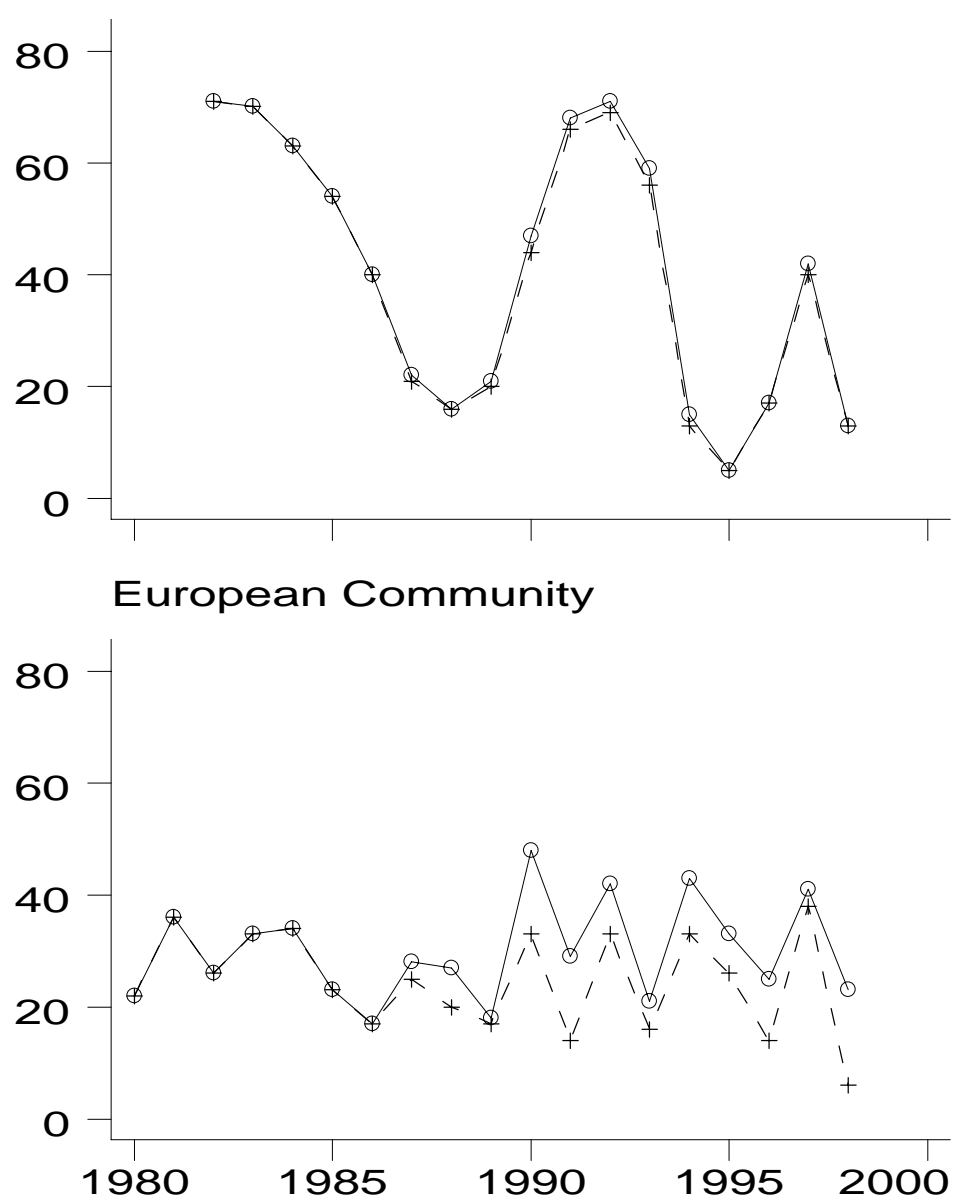

+ Total AD Filings, excl. steel

Canada

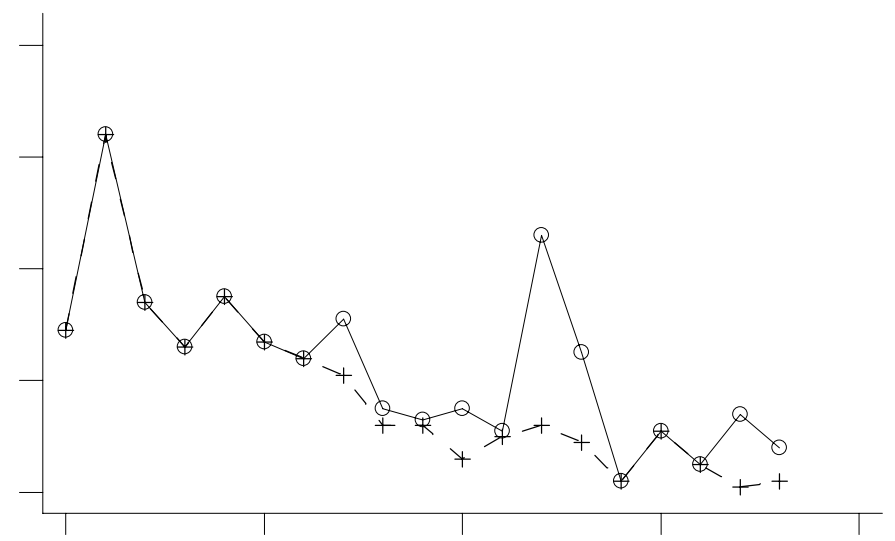

USA

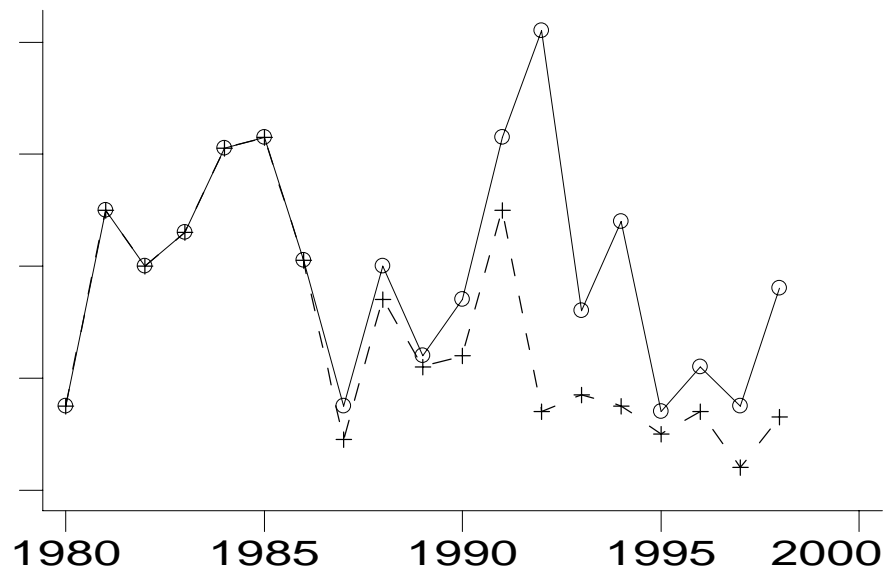

AD Filings

Figure 1 